\title{
Exploring Servitization in China
} Challenges of Aligning Motivation, Opportunity and Ability in Coordinating an External Service Partner Network

Raja, Jawwad Z.; Frandsen, Thomas

Document Version

Accepted author manuscript

Published in:

International Journal of Operations and Production Management

DOI:

10.1108/IJOPM-12-2015-0755

Publication date:

2017

License

Unspecified

Citation for published version (APA):

Raja, J. Z., \& Frandsen, T. (2017). Exploring Servitization in China: Challenges of Aligning Motivation, Opportunity and Ability in Coordinating an External Service Partner Network. International Journal of Operations and Production Management, 37(11), 1654-1682. https://doi.org/10.1108/IJOPM-12-2015-0755

Link to publication in CBS Research Portal

\section{General rights}

Copyright and moral rights for the publications made accessible in the public portal are retained by the authors and/or other copyright owners and it is a condition of accessing publications that users recognise and abide by the legal requirements associated with these rights.

\section{Take down policy}

If you believe that this document breaches copyright please contact us (research.lib@cbs.dk) providing details, and we will remove access to the work immediately and investigate your claim. 


\title{
Exploring Servitization in China: Challenges of Aligning Motivation, Opportunity and Ability in Coordinating an External Service Partner Network
}

\author{
Jawwad Z. Raja and Thomas Frandsen
}

Journal article (Accepted manuscript)

CITE: Exploring Servitization in China : Challenges of Aligning Motivation, Opportunity and Ability in Coordinating an External Service Partner Network. / Raja, Jawwad Z.; Frandsen, Thomas. In: International Journal of Operations and Production Management, Vol. 37, No. 11, 2017, p. 1654-1682.

This article is (0) Emerald Group Publishing and permission has been granted for this version to appear here: https://research.cbs.dk/en/publications/exploring-servitization-in-china-challenges-of-aligning-motivatio. Emerald does not grant permission for this article to be further copied/distributed or hosted elsewhere without the express permission from Emerald Group Publishing Limited.

DOI: 10.1108/IJOPMI-12-2015-0755

Uploaded to CBS Research Portal: January २०19 
Paper accepted for publication in:

\section{International Journal of Operations and Production Management}

Volume 37, Issue 11, Pages 1654-1682.

Raja, J.Z \& Frandsen, T.

\section{EXPLORING SERVITIZATION IN CHINA: CHALLENGES OF ALIGNING MOTIVATION, OPPORTUNITY AND ABILITY IN COORDINATING AN EXTERNAL SERVICE PARTNER NETWORK}

Citation:

Raja, J.Z. \& Frandsen, T. (2017) Exploring servitization in China: Challenges of aligning motivation, opportunity and ability in coordinating an external service partner network, International Journal of Operations and Production Management, Vol. 37, Iss. 11, pages 16541682.

\section{Corresponding author details:}

Dr Jawwad Raja

Copenhagen Business School

Department of Operations Management

Solbjerg Plads 3

Frederiksberg

Denmark

Tel: +4538152416

Email: jr.om@cbs.dk

\section{Acknowledgements}

The work presented here was undertaken at Copenhagen Business School as part of the 'Driving Competitiveness through Servitization' project, which is supported by the Danish Industry Foundation (Project number: 2014-0095). We would like to acknowledge the research support provided by Anders Park Egedal, Kai Inga Basner and Lauren Pflueger. Earlier versions of this paper were presented at the EurOMA 2015 conference in Nuechtal, Switzerland and at the Academy of Management 2016 conference in Anaheim, CA, USA. We are grateful for the comments of the participants at these conferences. We also acknowledge the constructive comments provided on earlier drafts by Jan Mouritsen, Dane Pflueger, Christian Kowalkowski, Daniel Kindström and Alexey Sklyar; all remaining errors remain our own. Lastly, we acknowledge the many helpful comments from the special issue editors and the two anonymous reviewers. 


\title{
EXPLORING SERVITIZATION IN CHINA: \\ CHALLENGES OF ALIGNING MOTIVATION, OPPORTUNITY AND ABILITY IN COORDINATING AN EXTERNAL SERVICE PARTNER NETWORK
}

\begin{abstract}
Purpose - Previous research has predominately focused on the servitization strategies of Western manufacturers in advanced economies, neglecting the potential for servitization in those which are emerging, such as China. This paper explores the role of the external service partner network of a European manufacturer providing services in China, in order to develop a better understanding of the resulting and associated challenges.
\end{abstract}

Design/methodology/approach - An in-depth case study approach was used to examine the parent company, its subsidiary in China and the related service partner network. Data collection involved all three actors and took place in Denmark and China.

Findings - The findings suggest that motivation, opportunity and ability (MOA) need not only be mutually reinforcing for the organization attempting to move towards services but also aligned between organizational units, as well as with the service partner network. Furthermore, the findings suggest that while service partners are typically closer to the market, they may not be able to deliver the higher value-added services requiring customization.

Research limitations/implications - This study is limited to a single manufacturer attempting servitization in China. Future studies may consider other case firms in other markets.

Practical implications - The MOA framework provides a basis for understanding the managerial challenges of aligning and coordinating the MOA elements amongst different actors.

Originality/value - This paper contributes by exploring servitization in an emerging market through the MOA framework in order to better understand the challenges and complexities. Servitization is found to be a dynamic phenomenon which should be understood as a movement that is also dependent on an external service partner possessing the necessary capabilities. In turn, this requires understanding the MOAs of all actors in a network and how they may be influenced in order for the MOA elements to be mutually reinforcing.

Keywords: servitization; service network; China; MOA

Paper type: Research paper 


\section{INTRODUCTION}

Servitization as a means of competitiveness is widely discussed in the extant literature in the context of, and by reference to, developed economies (Vandermerwe and Rada, 1988; Wise and Baumgartner, 1999; Baines et al., 2009). For many Western manufacturers, services now constitute an important part of their business. For the most part, the provision of advanced services and solutions is suggested as an effective means by which to respond to competitors from emerging economies in home markets (Neely, 2007). The literature largely seems, however, to ignore the opportunities that emerging and global markets may present for the provision of services, with few notable exceptions (e.g. Kucza and Gebauer, 2011; Vandermerwe and Chadwick, 1989; Demeter and Szász, 2013; Szász and Demeter, 2015). As a result, understanding the global perspective in terms of service is considered a research priority (Ostrom et al., 2015).

It is suggested that the motivations of Western manufacturers for locating activities in emerging economies are changing (Kinkel, 2012). Increasingly, it is submitted that the emerging economies are targeted in order to seek access to growing markets, rather than purely to obtain low cost production advantage (Reiner et al., 2008). Whilst product sales in emerging markets are growing, empirical evidence suggests that there remains significant growth potential in services (Neely et al., 2011). Although tapping into this potential is increasingly of strategic importance, many Western manufacturers are finding it difficult to actually realize the opportunity ( $c f$. Gebauer, 2006). It is not clear from the literature what the challenges are when it comes to services, nor how Western manufacturers may exploit opportunities for service provision in new markets. Further insight is therefore needed as to how organizations may be able to pursue those opportunities and manage the likely challenges. China is one such emerging market that presents an opportunity for company expansion. In particular, there is a need to examine the role of external partner organizations in a network that may be mobilized in an attempt to realize such opportunities (Spring and Araujo, 2013). Thus, in this context, the managerial challenge of aligning and coordinating efforts within a network requires consideration.

In order to understand the challenges and inform managerial practice as to the use of an external service partner network, we adopt the motivation-opportunity-ability (MOA) framework (MacInnis et al., 1991; Rothschild, 1999; Blumberg and Pringle, 1982; Bourdeau et al., 2003). We suggest that an external service partner network needs to be motivated to behave in a way which is congruent with the goals of the parent firm, and that it should not act purely on the basis of selfinterest. To do so requires the parent firm to provide the opportunity and ability for subsidiaries and service partners to deliver. This is further complicated by the need to coordinate efforts between different actors with the realization that decisions made to change an aspect of MOA of one actor can influence the MOA elements of other actors in a network. This framework is a useful means by which to understand an area of research that is relatively sparse when it comes to considering the role of external organizations. The research presented here therefore begins to address this gap by exploring the following research questions:

$R Q 1$ : $\quad$ How does MOA influence the provision of services in an emerging market amongst the different actors involved?

$R Q 2$ : $\quad$ What challenges do manufacturers experience in expanding service provision through an external service partner network? 
In order to investigate these questions, an in-depth case study approach was adopted. A Danish manufacturer of complex equipment and provider of services and solutions, operating globally and expanding into the Chinese market, was selected. Data collection involved spending time at the firm's headquarters in Denmark, the offices of its Chinese subsidiary and interactions throughout the external service partner network in China.

The study provides a number of contributions to the extant servitization literature. Firstly, we argue that there is a need to go beyond concentrating on the focal firm in attempting to understand the inherent challenges of enacting a servitization strategy in an emerging market. One way to do this is to use the MOA perspective to explore those challenges as they are experienced by the different actors involved. Secondly, we present empirical insights from the in-depth case study. Thirdly, we suggest that servitization is a dynamic phenomenon and should be understood as a movement that is dependent on capabilities possessed by external service partners, thus there is the need to understand and align the MOA of all actors involved in order for it to be mutually reinforcing. As such, different MOA elements are best understood as managerial issues of alignment and coordination.

The remainder of the paper is structured as follows: in Section 2, we review the literature on servitization in China, the supply network considerations and introduce the MOA framework. We then, in Section 3, set out our research methodology, including a detailed explanation of the data collected and analysis procedures adopted. A brief overview of the case company and the Chinese context is presented in Section 4. In Section 5, the findings emanating from the study are presented and are followed, in Section 6, by a discussion and conclusion, outlining the contributions, limitations and suggestions for further research in relation to our adopted framework.

\section{LITERATURE REVIEW}

\subsection{Servitization in China}

Neely (2008) reported that "there tend to be more manufacturing firms that have servitized in highly developed economies than in industrialising economies" (p. 114). In the same study, Neely states that, at that time in China, most firms only manufactured (99\%). It has subsequently been reported, however, that, in a short period, Chinese firms have rapidly increased their levels of servitization, from less than $1 \%$ to $19.33 \%$ (Neely et al., 2011).

With such a drastic rise in the level of servitization in a market as large as China, it is surprising that greater attention has not been devoted to how Western manufacturers may seek opportunities in emerging markets. From a search of the literature, it is clear that, to date, there have been only a limited number of research studies focusing on servitization in China (see Table 1 for overview). Of these studies, half are based on Swiss companies operating in China (Gebauer et al., 2011; Gebauer et al., 2007; Gebauer and von Zedtwitz, 2007; Gebauer, 2006; 2007), whilst three focus purely on Chinese firms (Gebauer et al., 2008; Gebauer and Fischer, 2009; Li, 2011). One study is based on a database search (Neely et al., 2011) and one is based on Western manufacturers, yet the sample is unexplained (Fischer et al., 2008). Methodological approaches used range from surveys to case studies to a combination of the two (see Table 1). 
Despite the limited research, the findings from certain of these studies provide potentially interesting insights. Revenues from services seem to account for less than half from Chinese subsidiaries (rather than their Swiss counterparts) (Gebauer, 2007), which is attributed to cultural characteristics such as guanxi (personal relationships), renqing (exchanging favors), and mianzi (preserving dignity) (Gebauer et al, 2007). It also appears that adapting Western practices used in mature markets for use in China is not straightforward (Gebauer et al., 2011; Fischer et al., 2008) and that there are a number of hurdles pertaining to strategy formulation and implementation, along with cognitive hurdles, that need to be overcome in lower-end markets (Gebauer, 2006). It is thus proposed that Western manufacturers ought not to focus on the premium segment but consider the mid-market segment and may thereby unlock the revenue potential of the mid-market, while also mitigating the risk of competitors entering through the lower-end market (Fischer et al., 2008). Others warn against the extent to which practices in mature markets should be adapted for the Chinese context (Gebauer et al., 2011). Furthermore, previous studies suggest that Chinese companies often restrict their maintenance strategies to corrective maintenance, opting not to implement predictive or total productive maintenance (TPM) programs or outsource maintenance (Gebauer et al., 2008). In attempting to provide services, other challenges pertain to the lack of qualified workers and managers in China and the lack of goal alignment when partners collaborate (Gebauer, 2007). This would clearly impact the provision of more advanced services in this market, especially for solutions which necessitate supplier integration and co-production with customers (Zhang et al., 2016).

If, as suggested by Neely et al. (2011), an increase in levels of servitization is occurring in China, then Western manufacturers need to be cognizant of the opportunities that may present themselves, particularly in light of the size of the market and the installed base of products that require service. Importantly, manufacturers need to clearly articulate their strategies, in order to be able to achieve such opportunities and develop the necessary capabilities. The type - or extent - of servitization will also have a bearing on the capabilities needed at a local level. Important considerations include the ability to customize service offerings to meet local needs versus attempting to deliver standardized service offerings dictated by the parent firm (see Matthyssens and Vandenbempt, 2010). For Western manufacturers embarking on servitization in markets such as China, the type of approach adopted-be it ethnocentric (that is, a home-country orientated perspective), polycentric (that is, a host-oriented approach in decision-making) or geocentric (being a worldoriented approach that sits between the home and host country) (Perlmutter, 1969) — is likely to impact the nature of the services provided. Important considerations in terms of how human resources are managed and the extent of autonomy in decision-making for strategy development are highlighted in respect of service development in manufacturing firms (Kucza and Gebauer, 2011). However, it may also be that the role of an external network to support the provision of services needs to be considered, especially in markets such as China, in which manufacturers may wish to provide coverage over a vast region. The supply network is then an important consideration that, to date, has not been given due attention in the servitization literature. 
Table 1-Research papers on servitization in China

\begin{tabular}{|c|c|c|c|}
\hline Author & Methodology & Sample & Key findings \\
\hline Gebauer (2006) & $\begin{array}{l}\text { Case studies from company } \\
\text { interviews }\end{array}$ & $\begin{array}{l}25 \text { mainly Swiss } \\
\text { manufacturers }\end{array}$ & $\begin{array}{l}\text { - Reasons why Swiss manufacturing companies operating successfully in high-end markets often fail in low-end } \\
\text { markets is due to: 1) cognitive hurdles; 2) structures limiting strategy formulation; and 3) hurdles in implementing } \\
\text { the strategy }\end{array}$ \\
\hline Gebauer (2007) & Not provided & $\begin{array}{l}\text { Comparison of } 23 \\
\text { Chinese and } 32 \\
\text { European subsidiaries } \\
\text { of Swiss OEM }\end{array}$ & $\begin{array}{l}\text { - } 23.2 \% \text { of total revenue from European subsidiaries, with only } 10.3 \% \text { from Chinese subsidiaries } \\
\text { - Five main reasons provided: 1) strong competition, 2) cultural differences, 3) establishing a profitable service } \\
\text { business, 4) availability and education of Chinese workers and managers, and 5) differing goals among collaborating } \\
\text { partners }\end{array}$ \\
\hline $\begin{array}{l}\text { Gebauer \& Von } \\
\text { Zedtwitz (2007) }\end{array}$ & $\begin{array}{l}\text { Qualitative and quantitative } \\
\text { approaches }\end{array}$ & $\begin{array}{l}\text { Swiss companies } \\
\text { operating in China } \\
\text { with } 23 \text { mini-case } \\
\text { studies }\end{array}$ & $\begin{array}{l}\text { - Compared to Western companies, Chinese service organizations generate lower financial service-related } \\
\text { performance outcomes }\end{array}$ \\
\hline $\begin{array}{l}\text { Gebauer, Wang, } \\
\text { Beckenbauer \& } \\
\text { Krempl (2007) }\end{array}$ & $\begin{array}{l}\text { Combination of qualitative } \\
\text { research: interviews, } \\
\text { longitudinal study and } \\
\text { bipolar case studies }\end{array}$ & $\begin{array}{l}\text { Swiss company, } \\
\text { Chinese customers }\end{array}$ & $\begin{array}{l}\text { - Characteristics of Chinese culture impact how revenues from services are generated, as follows: } \\
\text { - Long-term orientation: bind customers by offering free services } \\
\text { - Guanxi (personal relationships), renqing (exchanging favors), and mianzi (preserving dignity): free customer } \\
\text { service to protect and strengthen the "faces" of both the company and the customer }\end{array}$ \\
\hline $\begin{array}{l}\text { Fischer, Gebauer \& } \\
\text { Fleisch (2008) }\end{array}$ & $\begin{array}{l}\text { Summary of authors' } \\
\text { experiences }\end{array}$ & Not provided & $\begin{array}{l}\text { - Western manufacturers should not only focus on premium segments, but also seek to enter the Chinese medium } \\
\text { market segment }\end{array}$ \\
\hline $\begin{array}{c}\text { Gebauer, Pütz, } \\
\text { Fischer \& Lin (2008) }\end{array}$ & Questionnaire & Chinese companies & $\begin{array}{l}\text { - Maintenance strategies often restricted to corrective maintenance } \\
\text { - Very few Chinese firms have implemented predictive maintenance, total productive maintenance programs or } \\
\text { outsource maintenance }\end{array}$ \\
\hline $\begin{array}{l}\text { Gebauer \& Fischer } \\
\text { (2009) }\end{array}$ & $\begin{array}{l}\text { Personal structured and } \\
\text { unstructured interviews }\end{array}$ & Chinese companies & $\begin{array}{l}\text { Explore } 5 \text { different clusters for service needs in China: 1) Highly price-sensitive on basic service needs; 2) Highly } \\
\text { sensitive on logistics performance of basic service needs; 3) Preventing product breakdowns for very reasonable } \\
\text { prices; 4) Knowledge seeking; and 5) Seeking cost-efficient outsourcing partners }\end{array}$ \\
\hline $\begin{array}{l}\text { Gebauer, Kucza \& } \\
\quad \text { Wang (2011) }\end{array}$ & $\begin{array}{l}\text { Exploratory focus group } \\
\text { and single case study }\end{array}$ & $\begin{array}{l}\text { European capital } \\
\text { goods manufacturer } \\
\text { operating in China }\end{array}$ & $\begin{array}{l}\text { - Performance benchmarks of the supply chain of spare parts is not always helpful in Asia/China } \\
\text { - Taking logistics practices from mature markets and adapting them to Asia/China does not necessarily work }\end{array}$ \\
\hline $\operatorname{Li}(2011)$ & Survey & $\begin{array}{l}403 \text { manufacturers in } \\
\text { China }\end{array}$ & $\begin{array}{l}\text { - Two critical factors create service-based value-added integrated solutions: } \\
\text { 1) Cross-functional information dissemination competence } \\
\text { 2) Joint development competence }\end{array}$ \\
\hline $\begin{array}{l}\text { Neely, Benedettini \& } \\
\text { Visnjic (2011) }\end{array}$ & Company profiles & OSIRIS database & $\begin{array}{l}\text { - } \quad \text { Many countries did not experience a significant shift in servitization levels from } 2007 \text { to } 2011 \\
\text { - } \quad \text { Chinese companies moved from less than } 1 \% \text { servitization in } 2007 \text { to } 19.33 \% \text { in } 2011\end{array}$ \\
\hline $\begin{array}{l}\text { Zhang, Zhao, Voss \& } \\
\text { Zhu (2016) }\end{array}$ & $\begin{array}{l}\text { Multi case study approach: } \\
11 \text { initial case studies } \\
6 \text { case companies using } \\
\text { replication logic }\end{array}$ & $\begin{array}{l}\text { Chinese companies } \\
\text { from the Pearl River } \\
\text { Delta in Guangdong } \\
\text { province }\end{array}$ & $\begin{array}{l}\text { - Services have a role in innovation } \\
\text { - Support services and internal integration allow for knowledge from customers, which enables innovation } \\
\text { - Solution services allow demand to be answered in an innovative way by enhancing existing or imitated products } \\
\text { - To offer solution services, it is necessary to engage both in supplier integration and co-production with customers }\end{array}$ \\
\hline
\end{tabular}




\subsection{Supply network considerations}

Whilst there is a growing body of literature on buyer-supplier relationships within a servitization context (Bastl et al., 2012; Finne and Holmström, 2013; Saccani et al., 2014), these studies do not delve into the challenges of alignment and coordination within an inter-firm network in this context. Studies have shown that to create value for customers through servitization, complex supply network configurations may be required (Windahl and Lakemond, 2006; Chakkol et al., 2014). Rather than invest and develop local market knowledge and capabilities to deliver services internally, an alternative may be to use and develop an external service partner network (Kowalkowski et al., 2011; Chakkol et al., 2014; 2015). Reliance on an external partner network offers opportunities to develop the reach of the firm without investing in developing an internal service capability (Kowalkowski et al., 2011). While relying on service provision beyond the firm's boundaries is often necessary to grow the service business or deliver complex services, it increases the need for business network cooperation and holistic management of inter-firm dependencies (Kowalkowski, 2011; Kowalkowski et al., 2016). Kowalkowski et al. (2011) take an important first step in identifying several factors to determine whether manufacturers rely on internal, external or hybrid service provision, as well as the challenges associated with each choice. They do, however, highlight that, while empirically grounded in multiple case studies, their conclusions are not based on data collected from external service providers. Whilst recognizing that the motives of the manufacturer and service partner may be incongruent, they do not elaborate further by unpacking this important issue. Thus, amongst the servitization strategies of Western manufacturers, the reliance on external service providers seem to be a relatively salient but underexplored area.

Although the development of a partner network of external service providers reduces, to an extent, the need to develop internal capabilities, it also introduces complexities in terms of ensuring consistent service delivery and managing supplier relationships (Lambert and Cooper, 2000). It is also shown within a servitization context that what is important is not necessarily whether a single "close" or "collaborative" relationship exists, but, instead that "a combination of multiple configurations consisting of varying relationships dimensions and exogenous factors" are at play (Karatzas et al., 2016, p. 1). Within networks with multiple organizations and sites, there is then the challenge of coordination and achieving harmonization, for which high performance is more difficult to achieve (Rudberg and Olhager, 2003).

To date, this aspect has received limited attention in the servitization literature. This is curious, since the desire to develop service operations in emerging markets appears to be gaining strategic importance for many Western manufacturers. Of particular interest are larger markets, such as China, which present opportunities for the provision of services as they mature, yet also significant challenges. The role of the service supply network therefore requires further attention. As noted by Spring and Araujo (2013), a firm's network can play a large role in realizing a productive opportunity. In turn, relying on a supply network requires that the firm thoroughly understands its customers, and, importantly, how its suppliers can contribute to value creation. We propose that the MOA framework is a useful basis for exploring the managerial challenges which manufacturers providing services may encounter when working with an external partner network. This is discussed next. 


\subsection{The MOA framework}

It is suggested in the literature that human behavior can be seen as a function of a person's motivation, opportunity and ability (MOA) and that these three factors, when taken together, are antecedents to action (Blumberg and Pringle, 1982; Boxall and Purcell, 2016; Siemsen et al., 2008). The MOA framework has proved particularly useful in understanding a range of areas, such as marketing (Andrews, 1988; MacInnis and Jaworski, 1989; Rothschild, 1999; Binney et al., 2003), operations and supply chain management (Siemsen et al., 2008; Kim et al., 2015), knowledge management (Argote et al., 2003; Reinholt et al., 2011), and human resources (Blumberg and Pringle, 1982; Katz et al., 1985; Delery and Shaw, 2001; Bos-Nehles et al., 2013; Boxall and Purcell, 2016). While the order of letters in the acronym is used interchangeably across the different domains, the M-O-A combination is most frequent.

Motivation is considered an important force in steering behavior toward outcomes which are perceived as desirable (Boudreau et al., 2003) and has a strong self-interest component (Rothschild, 1999). This concept includes factors such as willingness, readiness, interest or desire (MacInnis et al., 1991), which set a person or organization up for action in terms of the effort they are willing to exercise if they can see the benefits. Opportunity concerns situations in which the benefits of acting towards a certain goal are clearly discernible. The willingness on the part of the individual or firm may be present but the means by which to achieve that goal may not. Thus, it is necessary to understand how conducive a given context or situation is to realizing the identified opportunity. Lastly, ability concerns the necessary skills, knowledge, attitude and behavior required to achieve the desired goal. These three MOA elements are suggested to be mutually reinforcing (Blumberg and Pringle, 1982; Johnstone at al., 2014) and important in directing behavior, especially amongst collaborating partners (Gebauer, 2007; Zhang et al., 2016). An understanding of the mutually reinforcing nature of the elements is key, as it logically follows that including all three in any analysis is crucial.

However, before borrowing theories such as MOA, it should be recognized that they may exist at different levels (Hitt et al., 2007; Bastl et al., 2013; Boxall and Purcell, 2016). In using the MOA framework - being an individual level approach to human behavior which we are translating to an organizational level -it is necessary to "ensure functional equivalence or how a theory retains its explanatory and predictive power when transferred between levels" (Bastl et al., 2013, p. 14). Such an approach, known as "vertical theory borrowing" (Whetten et al., 2009), is considered acceptable on the basis that the concepts are functionally similar across levels (Morgeson and Hofmann, 1999; King et al., 2010; Bastl et al., 2013).

Within Operations and Supply Chain Management (OM/SCM), vertical theoretical borrowing is not uncommon. Examples of previous studies which have adopted the approach exist in the extant literature (see Choi and Wu, 2009; Li and Choi, 2009; Bastl et al., 2013). There are also examples of the MOA framework being applied at an intra-organizational level (Reinholt et al., 2011), and more specifically within a SCM context, to buyer-supplier knowledge sharing (Kim et al., 2015).

We posit that the MOA framework has the potential to extend our understanding of the servitization domain. In particular, we believe there is value in using the framework within a supply network context in order to understand the challenges in realizing a servitization strategy in an emerging market, such as China, and how the different elements in the framework interact 
with each other in relation to the different actors (organizations) in a network. According to Scott and Davis (2015), "organizations are not only contexts influencing the activities of individuals they are actors in their own right" (p. 6). As such, individuals and organizations alike are motivated by their self-interest, identifying opportunities that become available and acquiring the ability to achieve them. On this basis, we argue that there is a precedent of using the MOA framework at the organizational level and that functional equivalence is preserved in so doing.

\section{RESEARCH METHODOLOGY}

Given that we wished to consider servitization in an underexplored empirical context, an exploratory qualitative case study approach was selected as the most appropriate research methodology. Access to a large Danish manufacturer of capital equipment was secured. The company has a global presence, spanning four continents and operating in many different markets. China was deemed to be the second home market for the company, where it sought to grow its market share. As part of that growth strategy, the service business was specifically marked as an important area for attention. As such, the company and its approach made it a logical choice for an in-depth case study with embedded cases, displaying, as it did, a number of unique qualities and demonstrating characteristics of a revelatory case (Yin, 2009; Siggelkow, 2007).

The adopted research approach is best described as 'abductive' (Järvensivu and Törnroos, 2010; Dubois and Gadde, 2002); that is, an iterative approach in which there is movement back and forth between empirical data and theory. Such an approach allowed for our understanding to develop over the duration of the case research, as it adopts a middle ground between deduction and induction (Peirce, 1998 [1903]; Järvensivu and Törnroos, 2010) and allows for theory elaboration (Ketokivi and Choi, 2014). We began by conducting a thorough search of the literature to identify what had been written previously about servitization in a Chinese context, before embarking on data collection. Throughout the data collection we constantly referred back to the literature to inform our next steps as is described below.

\subsection{Data collection}

Preliminary discussions were held with key gatekeepers of the case firm, hereafter referred to under the pseudonym 'EngCo', in order to secure access. Data collection was conducted over two distinct phases. In the initial phase, data were collected from the manufacturer at its headquarters in Denmark, in order to better understand the organizational background and the service strategies being employed. More specifically, we probed the different elements of our MOA framework in order to better understand the EngCo Headquarters (HQ) perspective, based on the literature. A number of key informants in the corporate service division were interviewed, alongside informal meetings with the Vice President for the service business. This process was helpful in providing an overview from the parent company's perspective.

In the second phase, data collection took place in Shanghai, China, working with employees in both the product and service businesses at various levels, from service coordinators to managers and directors. In this phase, we were able to understand how service was considered and implemented in the Chinese subsidiary. We asked respondents in the subsidiary about the different elements of the MOA from their perspectives. During the course of the initial interviews, it became apparent that the external authorized service partner network (ASPN) was also important in the delivery of services to customers and, accordingly, interviews were conducted with representatives 
from a number of those authorized service partners (ASPs). As such, we revisited the literature in the servitization and supply network domain to try and better understand the role of external ASPs. During the six-month data collection phase in China, one researcher was present in the country, visiting the subsidiary offices and the service partners. Throughout this period, the researchers discussed emerging issues and consulted the literature to continuously develop their understanding of the case firm. In so doing, the MOA framework was explored beyond the focal firm to include the external ASPN, which allowed us to consider the complexities and challenges of aligning and coordinating the different elements of the framework.

Data were gathered through semi-structured interviews, workshops, observations, site visits and an examination of company documentation. In total, 22 face-to-face interviews were conducted with selected staff and service partners over a 12-month period. Each interview lasted between 26 and 113 minutes and was conducted in an environment familiar to the interviewee, either at the employee's workplace or on customer sites. Interviews were recorded (with the consent of the respondent) and transcribed verbatim. In total, 17 hours and 42 minutes of recordings were transcribed (see Table 2 for an overview of data collected). 
Table 2 - Summary of data collected

\begin{tabular}{|c|c|c|}
\hline Case & Source of Data & Interviewee's position / Document \\
\hline \multirow[t]{2}{*}{ HQ } & Interview & $\begin{array}{l}\text { Business Development Manager A } \\
\text { Business Development Manager B } \\
\text { Senior Sales Manager } \\
\text { Vice President for Services }\end{array}$ \\
\hline & Document & $\begin{array}{l}\text { Global service strategy presentation } \\
\text { Sales and marketing material } \\
\text { Training manuals } \\
\text { Business press }\end{array}$ \\
\hline \multirow[t]{3}{*}{ China } & Interview & $\begin{array}{l}\text { Executive Manager } \\
\text { Business Development Manager C } \\
\text { Sales Operation Director } \\
\text { Service Supervisor Beijing } \\
\text { Service Supervisor South } \\
\text { Service Supervisor East } \\
\text { Service Supervisor } \\
\text { Service Coordinator } \\
\text { Service Coordinator } \\
\text { Concept Store Senior - Service Engineer }\end{array}$ \\
\hline & Workshop & $\begin{array}{l}\text { Service Workshop in Shanghai ( } 2 \text { day workshop attended by all } \\
\text { service partners) }\end{array}$ \\
\hline & Document & $\begin{array}{l}\text { Service plans } \\
\text { Performance data by region } \\
\text { Business plan }\end{array}$ \\
\hline \multirow[t]{2}{*}{ ASPN } & Interview & $\begin{array}{l}\text { Service Partner: Shanghai A } \\
\text { Service Partner: Shanghai B } \\
\text { Service Partner: Beijing }\end{array}$ \\
\hline & Document & $\begin{array}{l}\text { Certification } \\
\text { Awards for performance }\end{array}$ \\
\hline
\end{tabular}

\subsection{Data analysis}

The transcribed interviews resulted in approximately 600 pages of text. Initially, the data analysis commenced with each interview being thoroughly reviewed, with quotes and emerging themes identified, and then discussed among the researchers by reference to the transcripts. Our thinking constantly interplayed between data collection and analysis, based on how well the data fitted existing, modified or emerging understandings and its relevance to the observed phenomenon (Miles and Huberman, 1994). A template for analysis (King, 2004) was developed based on the literature, research questions and initial discussions for coding the data. All source material was uploaded and then coded using Nvivo software, for data analysis. The first-order codes were grouped into second-order abstract themes that reflected common features. This was an iterative process between emergent data and theoretical insights gleaned (Corbin and Strauss, 1990). Figure 1 provides a representation of the final data structure arrived at after a number of phases of data analysis based on the MOA framework. 
It is important to note that while Figure 1 may imply a linear process to the analysis of data, in practice, the process was far more iterative and entailed a process of systematically combining emerging insights across the case firm and the adopted framework (see Dubois and Gadde, 2002). As mentioned, the coding phase was first informed by an initial list of codes developed from the literature based on the MOA elements, in order to guide the process. Over the process of coding, the research team adjusted the coding structure by creating sub-codes and adding entirely new codes as they emerged. Moreover, certain codes were either merged or, upon reflection and discussion, deleted. In the analysis process, we also examined the relationship between the different elements of MOA for each of the actors and moved constantly between data and theory in order to understand how the different elements were either congruent or divergent for the different actors. This was an important step, as the extant literature tends to look only at an individual or group level. In this study, we contribute by elaborating on the MOA framework at an inter-organizational level (see Ketokivi and Choi, 2014). Table 3 provides an overview of the coded text based on the MOA framework. The findings from this process were written up in an indepth case study report, forming the basis for subsequent discussions with interviewees in both Denmark and China, in which we sought to verify the accuracy of our understanding.

Table 3 - The MOA Framework: theme description and frequencies

\begin{tabular}{clc}
\hline Theme & \multicolumn{1}{c}{ Overview } & Frequency of coded texts \\
\hline \multirow{3}{*}{ Motivation } & $\begin{array}{l}\text { Motivate actors to engage in some kind of behavior (e.g. } \\
\text { to offer services). Includes issues of furthering own } \\
\text { interests and pursuing beneficial situations for oneself. } \\
\text { Applied at an organizational and individual level. }\end{array}$ & $\begin{array}{c}\text { HQ data: } 134 \\
\text { China data: } 161\end{array}$ \\
& $\begin{array}{l}\text { Refers to outside factors that enable or constrain the } \\
\text { Opportunity }\end{array}$ & HQ data: 172 \\
& $\begin{array}{l}\text { occurrence of behavior. Includes environmental causes } \\
\text { such as market pressures or company strategies. Applied }\end{array}$ & China data: 263 \\
& at an organizational and individual level. & ASPN data: 52 \\
\hline \multirow{5}{*}{ Ability } & $\begin{array}{l}\text { Refers to personal or company-innate skills or traits that } \\
\text { mobilize or hinder action. Includes aspects such as } \\
\text { training, experience or competence. Applied at an } \\
\text { organizational and individual level. }\end{array}$ & HQ data: 271 \\
\end{tabular}




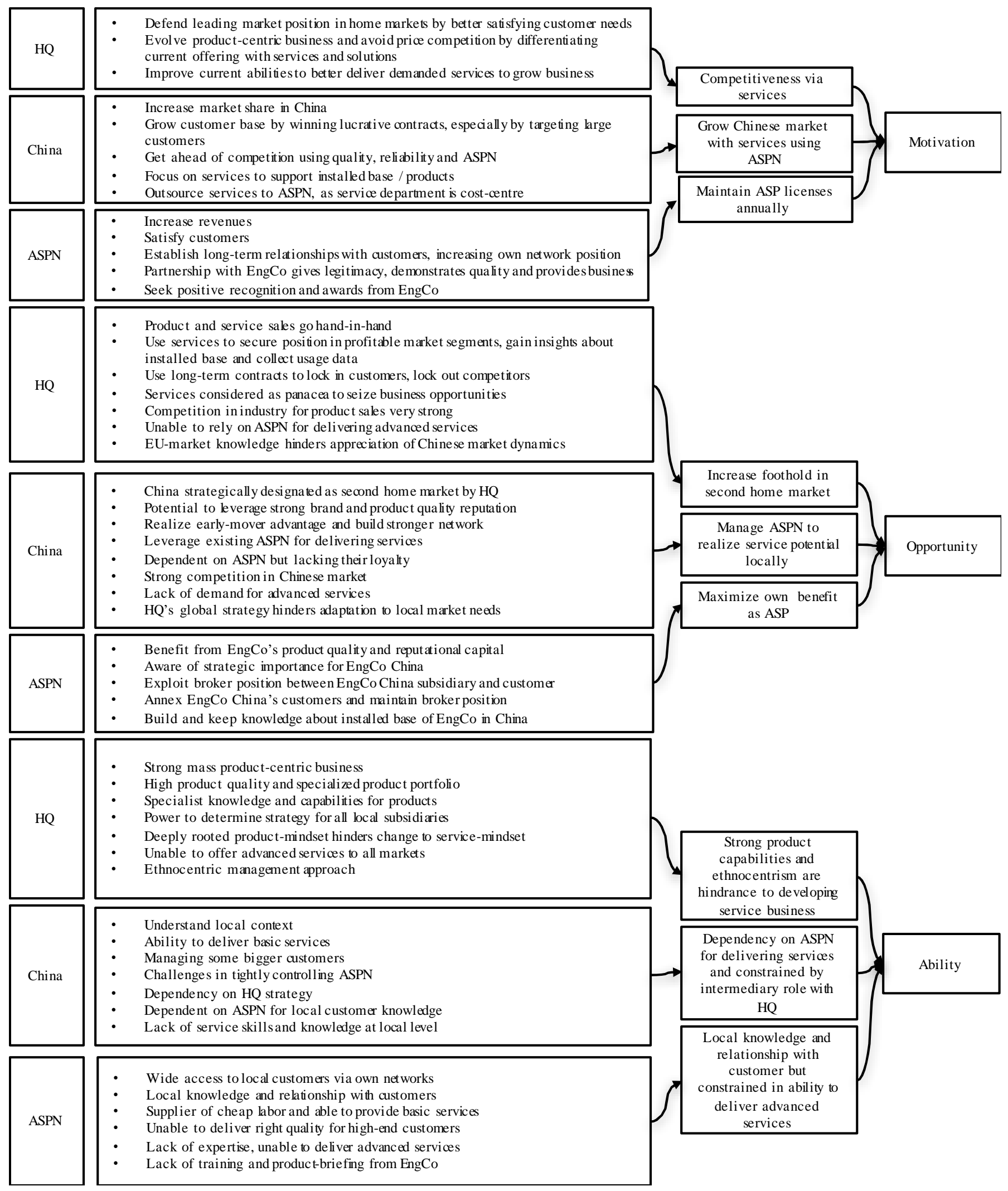

Figure 1: Coding structure 


\section{CASE DESCRIPTION AND CONTEXT}

EngCo is a large Danish manufacturer of capital equipment. It is known for delivering solutions to customers across an array of industries. At the time of the study, EngCo had, globally, approximately 18,000 employees.

EngCo provides an extensive range of products for the markets in which it operates. In excess of 16 million units are produced from the main product, accounting for approximately $50 \%$ of the company's global market. This mass production ability is considered a competitive advantage for, and by, EngCo. Consequently, it has a large installed base across the world. Europe is the largest contributor to global turnover, accounting for nearly two thirds, while Asia is the second largest, contributing close to $20 \%$ and showing the largest growth in recent years. Maintenance and service costs for the main product account for 5-10\% of the life cycle costs, which include labor costs, spare parts, transportation and cleaning of equipment. In recent years, EngCo has also developed and now provides customer solutions which address specific needs over the life of the product. This includes a full spectrum of service offerings with remote monitoring technologies that support the delivery of the offering and the ability to meet specific performance outputs.

For EngCo, China is designated the second home market and one which has seen a turnover increase of $19 \%$ in recent years. Since entering the Chinese market in the mid-1990s, EngCo has acquired a number of firms, in order to advance capabilities and penetrate the local market. It has also established a research and development (R\&D) center and a concept store. Within China, the business is divided into distinct regions. Consequently, China is a particularly important market for EngCo, yet the contextual nature of China posits challenges.

The strategic emphasis afforded to services by EngCo in Western markets has enabled it to provide solutions, such as the installation and operation of networks of products. As a consequence, it has managed to grow revenue from services and sees, in services, significant market potential. China is considered to provide an opportunity through which to replicate the offerings provided in Western markets on a larger scale. However, while in China repair and maintenance services are being provided, EngCo has not fully realized its aspiration to provide more advanced services and more widespread customer solutions. Whilst it has evidently faced challenges in implementing services in China, the firm has still outlined ambitious strategies to develop this part of its business. In doing so, it mirrors the success it has experienced in more mature markets (namely, Europe and USA), where it has demonstrated its ability to offer advanced services and solutions in which a range of capital equipment is integrated to address the greater needs of customers in setting up complex infrastructures. This involves solutions using its technologies in complex buildings, as well as structures such as manufacturing facilities for well-known Original Equipment Manufacturers and large recreational facilities.

In China, EngCo has also successfully sold solutions to pre-planned cities for development in managing complex infrastructures. As such, the HQ is motivated to replicate such success across other vast regions within the country. Understandably, this presents opportunities for growing the business. Specifically, employees interviewed at HQ recognized how, in addition to the products and services already sold in China, the strong technological competencies of the parent firm could complement and present further opportunities for ensuring the functional operation of large 
complex infrastructures. In particular, China as a coordinated market economy, with the related rapid expansion of infrastructure by the government, presents opportunities for advanced services and solutions which address the need for dependability and energy utilization of a large population.

Those employed by the local Chinese subsidiary consider, however, that customers in China have not reached the level of maturity of those in Western markets. The general sense is that the mentality of most Chinese customers does not favor the provision of advanced services and solutions. This presents a dilemma, as EngCo increasingly faces price competition from local competitors who have been reverse engineering equipment and providing copy-cat products to the Chinese market. The strategic importance of services is therefore both about securing product market growth and differentiation from competitors.

\section{FINDINGS}

In this section, the findings from the analysis process are presented in light of our research questions. We first address the MOA framework by reference to the different actors in the study - that is, EngCo HQ (the parent company, hereafter referred to as HQ), EngCo China (the Chinese subsidiary) and the ASPN. The challenges in expanding service provision are then presented.

\subsection{Motivation}

\section{EngCo $H Q$}

The motivation at HQ appeared to stem from the competitive landscape in which the company operates, with intense market pressures and a growing number of competitors. These competitors are increasingly capable of delivering quality products at a lower price point, perceived by some at HQ as a potential threat to the company's position as a "global leader" in the market. This is illustrated in the following:

\footnotetext{
"If we do not start working with solutions sales - differentiating us, we will be faced with competitors ... we will just be competing on price. And we are coming from completely different setups, and therefore we cannot compete on that, at all." (Senior Service Manager, HQ)
}

The motivation at HQ to withdraw from pricing competition was twofold. First, the strategic intent was to ensure the company was perceived differently to its competitors by avoiding action which might "duplicate or replicate what competitors are actually doing" (Business Development Manager A, HQ). Second, the focus was on customers and how products and services could be integrated into solutions that meet customer needs. In this respect, diversifying the current product portfolio, particularly with advanced service offerings, was seen as an effective way to better serve customer needs and thereby outperform competitors in China. Servicing such a wide portfolio of products, however, did present challenges (see Section 5.4). In addition, HQ wished to transfer solutions offerings delivered in other regions, such as Europe, to China.

As part of its global strategy, EngCo wished to ensure that services were delivered in a consistent manner. To this end, through HQ, sales were standardized and training manuals were produced for subsidiaries. This was seen as a way to safeguard a reliable product and ensure service quality, not only in China but also worldwide, as well as a means of offering greater value to customers whilst simultaneously building closer relationships. However, there was recognition that the return from services would take time to realize: 
“...my problem with service is, that it is not something that skyrockets our revenue numbers, it is something that you do on a longer term." (Business Development Manager B, HQ)

\title{
EngCo China
}

The importance of the Chinese subsidiary was clear, given that China was deemed the company's second home market. The intention of staff in China was to grow EngCo's customer base by securing lucrative contracts, in particular from larger customers such as municipalities or government bodies. The subsidiary took great pride in belonging to a global organization that was known for its product quality and brand reputation. This prestige motivated existing employees and attracted others to work for, or be associated with, EngCo. The staff recognized the importance of growing services in China as part of the strategy communicated by HQ, which is reflected in the following:

\begin{abstract}
"We want to sell knowledge, we want to sell solutions, we want to have those more advanced discussions with our customers. We would like...to help or educate them [customers] ...to take responsibility for environment and energy utilization by better understanding our technology." (Executive Manager, China)
\end{abstract}

However, it was felt that those communicating from HQ had been quite mild and less forceful in outlining their approach. Although servicing the installed base was considered a starting point, the service part of the business was designated as a cost center, which resulted in the provision of services being outsourced by the management of the subsidiary to the ASPN, as it was cheaper to perform services via the network than through hiring, training and using EngCo engineers. This is succinctly explained in the following:

“...in many cases the service business has been a cost center and then you can guess yourself how that has developed ... meaning that outsourcing service was much more feasible or ... attractive to the local general manager then having the service business in-house." (Business Development Manager A, HQ)

$A S P N$

The authorized service providers (ASPs) within the network were, understandably, motivated by their self-interest to increase revenues. In turn, they understood the need to satisfy customers and simultaneously establish good long-term relationships with them. Repeat business and customerto-customer recommendations were important in developing the ASP's local connections. In no small way, being an authorized partner of EngCo afforded great legitimacy when it came to performing services for customers and obtaining repeat business, as did the association with the EngCo brand and its quality products. This only acted to strengthen the position of the ASPN, especially given that the network possessed intimate knowledge of customers, which, in turn, made the providers valuable to EngCo when seeking to advance the service business in China.

For the ASPs, it was important to maintain cordial relations with EngCo China, primarily so they might remain ASPs. Each year, EngCo China re-accredits its ASPs, requiring them to meet a checklist of demands. Failure to meet the set criteria or underperformance makes an ASP susceptible to losing its license as an authorized partner. This acts as an important incentive for the ASPs to develop and maintain relations with EngCo China. Moreover, the ASPs seek to earn recognition and awards from EngCo China, though some ASPs commented on their rarity in recent times: 
“...today there are no benefits for the ASPs to reach the spare part sales target. Before, if they reach[ed] the target, they gave them a special reward at whole China ASPs meeting. So ASPs have no motivation to reach the target. I think we need to add motivation for ASP." (Service Supervisor East, China)

It can be gleaned from this that while motivating the ASPN was considered important, neither EngCo nor its subsidiary had taken concrete steps to ensure it ensued.

\subsection{Opportunity}

\section{EngCo $H Q$}

Services presented an opportunity to improve EngCo's foothold in the Chinese market. That opportunity was clearly acknowledged by senior management in HQ and formed an important part of the business strategy in China. Moreover, given the knowledge required to maintain advanced products, purchasing customers valued services. In turn, this was seen as impacting customer loyalty to EngCo, as services became more pivotal to the operations of its customers.

Services, which could be sold with a higher mark-up than products, were also considered a means by which to increase revenues. This was especially so for advanced services, which were seen as a way to secure future profitability and competitiveness for EngCo.

"...we would see huge business in [services]. Being able to stand out there and fix things. Also because we know our [products] so we should be able to utilize all the sensors and alarms and so on, to be able to make preventive service maintenance and thereby again servicing our customers better. It is so easy to turn this into a win-win situation for our customers." (Business Development Manager B, HQ)

In China, HQ wished to replicate some of the successes in advancing services and solution offerings it had enjoyed in European markets. Integral to this was capitalizing on the opportunity of integrating more information technology into products, with the aim of gaining intelligence about the installed product base and extracting data about customer usage. The opportunities resulting from the product performance data would allow monitoring services or, in some instances, the possibility of providing customized solutions to meet needs, which then added value. The strategic intent was clearly to sell longer-term service contracts that would lock-in customers - and lock competitors out where strong competition for products existed. This was considered to be dependent on having the right "set-up", as illustrated in the following:

\footnotetext{
"We need to get there, because there is a market there, this is where you can almost go if you are good enough you can take over the operation of the network. If you are good enough. And [if] you have the right setup. And there is huge money in it...." (Business Development Manager B, HQ)
}

Whilst services clearly presented opportunities in a market such as China, the challenge was how to go about delivering more advanced services. There was recognition of the need for specific capabilities when it came to advanced service opportunities, for which the ASPN was not equipped. In addition, there was a dependency on the ASPN for information. It was suggested that the ASPN occupied an important position given its proximity to the customer, and that EngCo often did not receive direct information and feedback from customers: it being received, instead, by the ASPN. To compound matters, HQ was unable to fully appreciate the dynamics and complexities of the Chinese market, where personal relationships with customers are important 
(Guanxi) (cf. Xin and Pearce, 1996). It was clear that implementing a similar approach to that employed in more mature markets, such as those in Europe, would not produce the same effects in China.

\section{EngCo China}

As aforementioned, given the opportunities for services, China had been designated EngCo's 'second home market'. Service was considered to afford an important opportunity by and through which product sales in China could be enhanced. However, unlike HQ, the Chinese subsidiary did not regard offering services as essential to its strategy to secure long-term growth. Rather, services were considered as one way to grow the business and to establish long-term relationships with important customers, but not the only or most important means. The subsidiary strongly considered product quality and brand reputation to be its key differentiating factors in the Chinese marketplace.

The subsidiary in China encountered difficulties in negotiating a locally adapted, yet centrally approved, strategy for dealing with its ASPN. This was further complicated by the fact that HQ and the subsidiary had different organizational setups. A senior service manager at $\mathrm{HQ}$, for example, was far more senior in the EngCo hierarchy than their Chinese counterpart. This meant that any coordination about services between the two needed to be mediated by a higher-ranking manager in China, who might be unable to delegate tasks optimally. External pressures revolved around international competitors seeking to also gain a foothold in the market, as well as newly emerging, local competitors that were reverse-engineering EngCo's products and selling them at cheaper prices.

A further, central challenge for the Chinese subsidiary has been exploiting the vast areas of the country that it has not yet penetrated. In this respect, the ASPN was considered an essential player, as it provided an important means through which to sell more products and parts and in these parts, was also required to push beyond the more basic services it tended to provide. This was particularly so as the Chinese subsidiary lacked the capabilities to provide services internally on a larger scale. Thus, the ability to exploit opportunities for service was highly dependent on the ASPN. The ASPN's local knowledge and its close personal relations with customers were considered key to move forward, although it did appear that those at the Chinese subsidiary felt that certain ASPs were not as committed to the provision of service as the subsidiary itself. Thus, in order to realize the opportunities that were present in the Chinese market, it was mentioned that:

"...from a service perspective, look into what capabilities, what competences is it actually that is needed, and based on that selecting which service partners are right [for us]." (Business Development Manager A, HQ)

The approach of the subsidiary clearly involved, if opportunities were to come to fruition, discerning the required capabilities and competencies in a service network.

\section{$A S P N$}

Interestingly, the ASPN was positioned to gain the most from the opportunities presented by EngCo's increased emphasis on service. The financial cost of using EngCo engineers to provide the type of service support required by a majority of customers at the low-end of the market was considered too high ( $c f$. Gebauer, 2006). Understandably, EngCo also did not wish to invest and 
manage a large dispersed service workforce at a stage when the relevant market was still maturing. Moreover, it was recognized that the demand for advanced services was not something that could be realized overnight. As such, this presented an opportunity for the ASPN to leverage its position between the Chinese subsidiary and the customers. This was acknowledged by the sales director in China, who commented that:

"...order information comes from the middle part, I mean either the licensed dealer or ASPN. How do you then know their [customer's] real needs? How do you know the real service level and customer satisfaction level?" (Sales Operation Director, China)

Knowledge of the installed base was not readily available to the subsidiary but was rather dependent on the ASPN. This evidently led to the ASPN prioritizing its self-interest, being to maximize revenues and maintain positions as key brokers. This is reflected in the following:

“...being an [ASP] gives us two legs. So first we sell the [capital equipment], and then we can provide services. It gives a good balance for the company. And the customer does not need to look to other places to find services." (Service Partner A, China)

Hence, the opportunities for the service partners were clear, given their positions in the network, something they would not give up lightly. Importantly, in order to realize those opportunities, the ASPN maintained knowledge of the installed base and had developed personal relationships with customers over time.

\subsection{Ability}

\section{Eng Co $H Q$}

EngCo's core capabilities lie in its product-centric mass production business, where it possesses strong technical knowledge and the ability to continuously innovate. The portfolio of specialized products is very large and designed to meet a diverse range of customer needs. The traditional product capabilities are considered to constrain EngCo in moving from a product mind-set to a service mind-set. This is illustrated in the following:

"We are coming from a box product world going into more complex offerings that require services that we are not that good at doing. So that is actually something preventing us from selling, that we are not good at services." (Senior Sales Manager, HQ)

It was acknowledged that EngCo has some way to travel if it is to match its ability in products with that which is required for services and solutions. Furthermore, the ethnocentric management approach may limit the ability to realize the complexities of local contexts in which subsidiaries operate.

Recognizing this need for development, HQ took an active role in expansion in the Chinese market, albeit from a distance. This is illustrated in the following comment:

"that China has become such an important part of [EngCo], you no longer let China run on their own anymore. Also in the realization that you have to invest more in China than you would before .... So the new world for China is to increasingly let itself become involved in the group, but obviously also influence what the group's priorities should be." (Executive Manager, China) 
At the time of the study, HQ relied on its ASPN to distribute products and provide basic services to its end customers. Since HQ sees difficulties in its current and future service delivery model, it relies heavily on its ASPN and needs its cooperation. Focusing chiefly on creating end-user benefits, HQ applies strict measures to bring its ASPN into compliance with HQ standards. For example, after it became known that some ASPs address, and seek to satisfy, their own interests first, HQ initiated a campaign to remove accreditations from substandard service partners.

\title{
EngCo China
}

The main strength of the Chinese subsidiary was its understanding of the local Chinese market. The most senior positions were occupied by Danish expatriates, yet most other managerial positions were filled by Chinese locals, in Shanghai and throughout the other regions. In taking this approach to personnel, the EngCo subsidiary was able to obtain customer insights and, to an extent, understand their needs. Until fairly recently, the focus in China had been on selling products, yet the strategy at the time of the study placed a greater emphasis on the need for growing service. In this regard, it was considered that the subsidiary lacked the ability to provide basic services on a wider scale, which the ASPN was able to, and did, deliver. Coupled with this was the challenge of managing the ASPs, who were considered to be closer to the customer:

\begin{abstract}
"But it is not okay to let the ASPN loose on their own, if I may say so. Because we are, at least that is a statement from my side, we are losing our customers if we let the partners run with the customers. We need to be in charge of the customer. .... It is not like that today. You see mixture of it of everything today in [EngCo] ... And you will see partners handling or dealing directly, and going out putting their own name tag over [our] logo in the installation." (Business Development Manager B, HQ)
\end{abstract}

HQ was concerned with the consequences of allowing the ASPN too much discretion over customer contact, fearing the resulting relationships between the ASPN and the customers might undermine EngCo.

EngCo's strategy was very much top-down, from the HQ in Denmark to the local subsidiaries. At the local level, the subsidiaries were required to prioritize service. However, in China, that was very much constrained by the dependency on the ASPN, which HQ considered a "necessary evil" at the early stage of making inroads into the Chinese market. Surprisingly, the successes of the ASPN were considered 'potential' lost opportunities, or even losses, for EngCo. Thus, senior management were alive to the need to align strategy. Corporate wide programs were considered integral, as the competency level in China was deemed too low for service provision, particularly of advanced services. EngCo China therefore faces a major constraint in its intermediary role, caught between a need to follow HQ's directives and also needing to address the peculiarities of the Chinese market.

\section{$A S P N$}

The ASPN was found to be in a strong position in respect of access to customers. Over time, the ASPN had accumulated local knowledge of customers and developed personal relationships, which played a key role when delivering services and acquiring the confidence of customers at the local level. Whilst opportunities for basic services were vast, the necessary skills to provide more advanced services were lacking within the ASPN.

\footnotetext{
"...some customers are very high end, and require high quality. And therefore choose [EngCo] service center instead of ASP." (Senior Service Engineer, China)
} 
So, whilst the ASPN had a wide network and clear access to customers over a broadly dispersed area, they were considered by EngCo to be no more than suppliers of cheap labor for basic services in the Chinese market.

Much of this was attributable to technicians within the ASPN not having received the necessary formal training, something which HQ tried to address through training manuals. However, that training was not deemed adequately tailored to the needs of high-end customers and it was also considered that it did not clearly demonstrate how to provide solution offerings. Coupled with the general feeling that the training originating from HQ may have been more extensive, those in the ASPN felt that they did not receive sufficient guidance or appropriate product briefings from the Chinese subsidiary, which consequently severely constrained their ability to deliver the quality of work required.

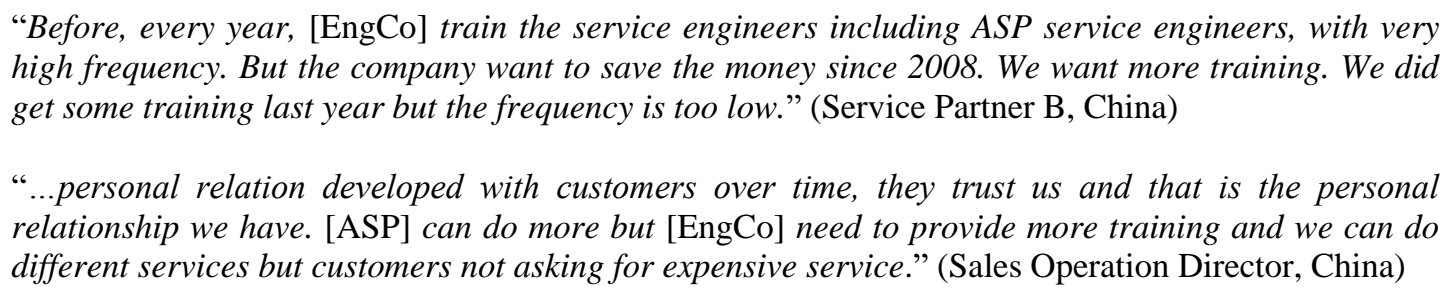

On the other hand, EngCo felt that the cost of training external partners to high levels risked the interests of the business and, instead, that such capabilities should be developed with internal engineers.

It is suggested that the Chinese subsidiary is unable to better manage its ASPN due to its dependency on HQ and its global strategy. Lastly, China faces stiff competition for skilled workers, and lacks especially skilled service engineers. Table 4 summarizes the key findings for the different actors in terms of their MOA. 
Table 4-Summary of key MOA findings and challenges

\begin{tabular}{|c|c|c|c|}
\hline & EngCo HQ & EngCo China & ASPN \\
\hline Motivation & $\begin{array}{l}\text { - Integrating products and services in solutions that meet } \\
\text { customer needs } \\
\text { - Grow business in home markets with services and solutions } \\
\text { - Strengthen company competitiveness with services to mitigate } \\
\text { against price competition from low cost manufacturers } \\
\text { - Establish longer-term focus with service } \\
\text { Challenges to motivation } \\
\text { - Difficulties in transferring solutions developed for mature } \\
\text { markets to the emerging market in China }\end{array}$ & $\begin{array}{l}\text { - Grow customer base in China } \\
\text { - Sense of belonging to EngCo } \\
\text { - Support service of installed base via ASPN } \\
\text { - Support customers with knowledge and solutions that can } \\
\text { address the need for efficient energy utilization } \\
\text { - Secure lucrative contracts with large customers } \\
\\
\text { Challenges to motivation } \\
\text { - Service business considered a cost center by local management } \\
\text { leading to outsourcing of service provision to ASPN }\end{array}$ & $\begin{array}{l}\text { - } \quad \text { Grow own business by increasing revenue } \\
\text { - } \quad \text { customers } \\
\text { - } \quad \text { Maintain authorized position with longer-term relationships with } \\
\\
\text { Challenges to motivation } \\
-\quad \text { Lack of rewards and recognition }\end{array}$ \\
\hline Opportunity & $\begin{array}{l}\text { - Targeting large public and private customers to provide } \\
\text { solutions for complex infrastructures } \\
\text { - To deploy advanced technology to remotely monitor and service } \\
\text { capital equipment } \\
\text { - Offering integrated product and service offerings with potential } \\
\text { to take over the operation of a network } \\
\text { - To increase revenues with service } \\
\text { - Fend off 'copy-cat' manufacturers by providing services } \\
\text { Challenges in realizing opportunities } \\
\text { - Service provision using external ASPN leads to unforeseen } \\
\text { path-dependencies as knowledge of installed base primarily } \\
\text { resides within the network } \\
\text { - Appreciating dynamics and complexities of Chinese market, } \\
\text { where personal relationships are important }\end{array}$ & 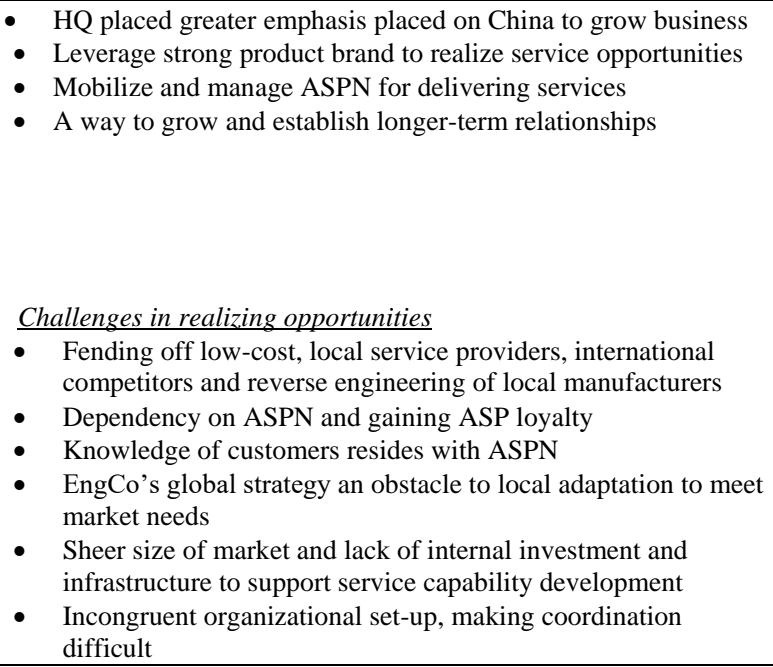 & $\begin{array}{l}\text { - Local knowledge of customer needs and installed base } \\
\text { - Long-term personal relationships with customers for selling } \\
\text { further services } \\
\text { - Ideally placed between EngCo and customer to be required by } \\
\text { both } \\
\text { EngCo China service engineers too expensive for low-end } \\
\text { market } \\
\begin{array}{l}\text { Challenges in realizing opportunities } \\
\text { Maintain accredited license from EngCo by delivering service } \\
\text { and meeting requirements }\end{array}\end{array}$ \\
\hline lity & $\begin{array}{l}\text { - Able to determine global strategy and take an active role in } \\
\text { shaping priorities in China } \\
\text { - Large portfolio of specialized capital equipment addressing } \\
\text { diverse customer needs } \\
\text { - Capabilities and knowledge of delivering high-end solutions in } \\
\text { other markets } \\
\text { Challenges in terms of ability } \\
\text { - Understanding and adaptation to local market context/needs } \\
\text { from HQ }\end{array}$ & $\begin{array}{l}\text { - } \quad \text { Knowledge of local context } \\
\text { - } \quad \text { Able to deliver advanced service and solutions in some areas } \\
\text { - } \quad \text { Highly skilled EngCo service engineers for large projects } \\
\text { through ASPN } \\
\text { Challenges in terms of ability } \\
\text { - } \quad \text { Lack ability to deliver basic services on wider scale } \\
\text { - } \text { High dependency on HQ for decision-making and resource } \\
\text { - Constrained in learning from other markets globally } \\
\text { - } \text { Dependency on ASPN for knowledge of installed base }\end{array}$ & $\begin{array}{l}\text { - } \quad \text { Local knowledge of customers } \\
\text { - Well positioned in social network (guanxi) with customers to } \\
\text { deliver service and highly trusted } \\
\text { Wide pool of labor to deliver basic services } \\
\text { Challenges in terms of ability } \\
\text { - } \quad \text { Lack knowledge and expertise for high-end segment of market } \\
\text { to deliver advanced services } \\
\text { - } \quad \text { Lack of training from EngCo for product and service offerings } \\
\end{array}$ \\
\hline
\end{tabular}




\subsection{Considering the challenges of expanding services in China}

Our second research question seeks to explore the challenges experienced in attempting to expand services via an external ASPN. A number of challenges were identified in realizing the service strategy in China. Operational managers were found to be extremely aware that, in China, EngCo operates in a highly competitive, growing marketplace which is undergoing rapid change. Several interviewees emphasized the need to view the challenges facing EngCo within a broader context. At the forefront of this argument were the changing needs of customers and the ways in which EngCo needs to respond. It was clear that the customer landscape was changing, both in the sense of volume of demand and in the types of desired services. Significant competitive advantages were seen to lie in the size of EngCo's extensive installed asset base. There was a general recognition of the need to leverage this installed base to secure extended service contracts from key customers. In part, this need for leverage stemmed from the fact that competitors are increasingly servicing EngCo's products. A further challenge lies in acquiring the ability and credibility to service competitors' products. To date, the Chinese market has not prioritized servicing competitors' products. Additional challenges included the emergence of copycats who are reverse-engineering EngCo products and offering non-original spare parts. It was clear that EngCo has been taken by surprise with the speed at which all this has occurred, and active steps were being taken to protect the spare parts business in China as a result. These challenges echo the opportunities seen by Chinese manufacturers turning towards services as a way to develop solutions that compensate for a lower technological level in the core product (cf. Zhang et al., 2016).

In HQ, service was increasingly considered strategically important, which was subsequently reflected in China being made the second home market. However, convincing customers of the bottom-line impact of extended service offerings was frequently presented as a key barrier to business expansion in China. Coupled with this was the need to strike the right balance between what the customer wanted, what technology could provide and how this sat with the wish to provide extended services. Moreover, it was recognized that any change in the customers' demands for service in China needed a longer-term orientation, focused on the market as it matured, before any significant impact would be made on EngCo's business. It was recognized that the maturity of the Chinese market varied greatly, both by region and type of customer.

The situation within EngCo China appeared to be that services were most often offered as an 'extra', appended following the sale of the product. This is understandable, given that the service business is fairly new in China. Moreover, whilst this move towards services was seen to provide access to resources for development projects, there was also a perceived lack of knowledge of the contextual nature of the Chinese market in HQ. This is aptly explained in the following:

"...many people in the headquarters do not have knowledge about the Chinese market. That makes it difficult for them to understand how the Chinese market is different from other markets. They often look at the mature markets as a model. [...] Without understanding that China is a much more immature market and that the Chinese understanding of service is not very developed." (Executive Manager, China).

The issue for debate was found to be the consistency of the service offerings delivered via the ASPN, which was responsible for customer contact. Coupled with this was the challenge of meeting the needs of existing customers whilst simultaneously striving to develop new market opportunities. Inevitably, managing an external ASPN was found not to be straightforward. 


\subsection{The dynamics of coordinating and aligning MOA for servitization}

The findings suggest the need to align the MOA elements to realize a servitization strategy, not only at the individual actor level but across actors. This is reflected in the empirical insights, which show that one element impacts the other elements within and across actors. Consequently, this presents the challenge of constantly attempting to achieve alignment by responding to the intended and unintended consequences of actions taken. As demonstrated, relying on a ASPN brings additional complexities of coordinating the actions of multiple actors in order to reach alignment. This implies that servitization is as much a managerial challenge of coordination and alignment as it is a structural challenge of crafting the right strategy and structure. Given that performance has multiple dimensions, as identified above in the form of the MOA elements which are mutually reinforcing ( $c f$. Blumberg and Pringle, 1982; Boxall and Purcell, 2016), it is necessary to understand the dynamic relationship between these elements.

These dynamics relate to the efforts of HQ to develop a service strategy which seeks to internally align the MOA. This strategy impacted EngCo's motivation, yet the abilities to realize the service opportunity had not yet been unearthed. To overcome this, HQ sought to support its Chinese subsidiary. This impacted the decisions made at EngCo China and caused it to increasingly rely on external service providers, which, in turn, created opportunities and motivation among the ASPN. The ASPN had the ability to provide services on a large scale. However, HQ realized that it lacked the capabilities to realize the Chinese opportunities, in terms of ensuring consistency of service delivery and the skills for more advanced services and solutions as part of the global service strategy. To develop the ASPN's ability to deliver, HQ sought to leverage its abilities and provide training to, and certification of, the ASPN. Figure 2 illustrates the MOA elements of each actor, with the arrows indicating how those elements impact on other elements within the network in a series of dynamics. 


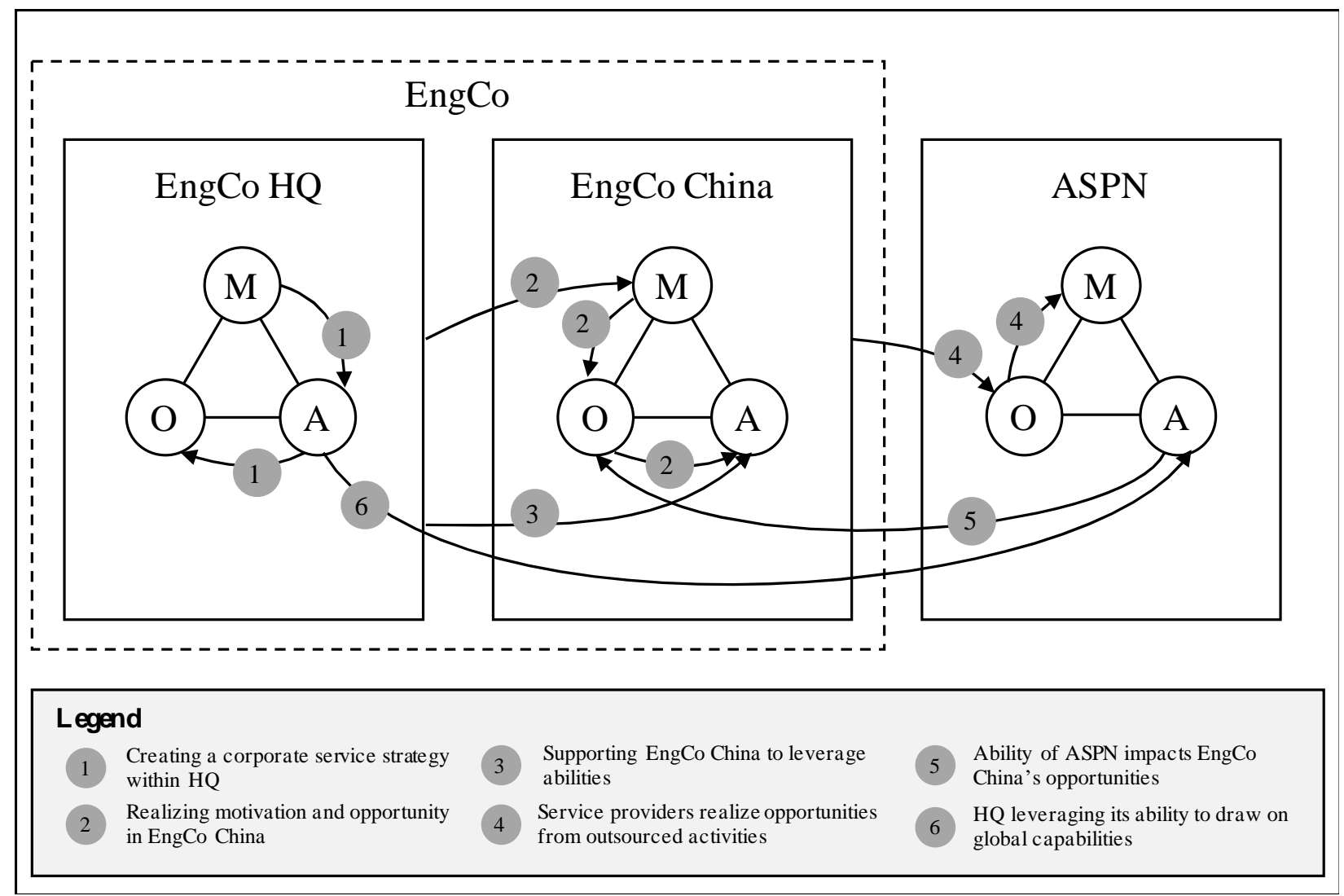

Figure 2: Dynamics of coordinating and aligning MOA in a service supply network

- Dynamic 1 - Creating a corporate service strategy within $H Q$ :

HQ was motivated to strengthen its business in China by emphasizing the provision of services. There were two primary motives: firstly, an intention to be perceived differently from competitors and secondly, to focus more on customers by combining products and services into solutions. Based on this motivation, HQ leveraged its ability as the locus of control and adjusted its corporate strategy to emphasize greater provision of services in China; in turn, creating new opportunities in an untapped and lucrative market for services. To a large extent, there are parallels here with previous studies that show the motivation of Western manufacturers to target the high-end market by utilizing their competencies (Gebauer, 2006).

- Dynamic 2 - Realizing motivation and opportunity in EngCo China:

EngCo China is generally motivated by the prospect of growing in its market and the local employees striving to make this business successful. EngCo China's main ambition is to grow its customer base, to secure lucrative contracts. As a result of HQ's initiative, services are highly regarded in China and employees are keen to offer them. As a consequence, the local employees were motivated to pursue and create opportunities for service sales, yet lacked the internal service technicians to grow the business. This, in turn, impacted EngCo's ability to provide services reliably across a country as vast as China.

- Dynamic 3 - Supporting EngCo China to leverage abilities:

We observed that the opportunity to grow the service business in China was recognized as a key priority in HQ, in line with the extant literature (Neely et al., 2011; Zhang et al., 2016). 
However, whilst the opportunity for growth was clearly discernible, the question of whether EngCo China possessed the ability to realize the opportunity was debatable. In an effort to push services, HQ had, in part, deployed expatriate managers to the Chinese subsidiary. The service strategy was relayed to local management, which considered the service business to be a cost center-the implication being that outsourcing service provision was considered more attractive than servicing through in-house capabilities.

- Dynamic 4 - Service providers realizing opportunities from outsourced activities:

EngCo China finds it relatively easy to hire new service partners as using the company brand, wearing its uniform and selling its services presents a great opportunity for ASPs. First and foremost, selling services can raise their revenues. What is more, due to limited control from EngCo China, service partners have the opportunity to increase their business further by acting opportunistically. For the ASPN, this presents a lucrative opportunity. Moreover, the network is positioned as an intermediary between EngCo and end customers, highly trusted by the latter and very knowledgeable about the installed base. In part, this gave rise to the opportunistic behavior. However, whilst the ASPN was able to provide support services to the low-end market ( $c f$. Gebauer, 2006), such as repair and maintenance, the move towards realizing opportunities for more complex offerings presented challenges. Thus, there existed a dependency on the ASPN, notwithstanding the fact that, at the time of the study, its ability to provide more advanced services had not yet been established.

- Dynamic 5 - Ability of ASPN impacts EngCo China's opportunities:

Realizing opportunities was dependent on the close relationships between customers and the ASPN, thus our findings, in line with others, show that understanding cultural peculiarities is of critical importance for Western manufacturers when seeking to realize opportunities in China (Gebauer, 2007; Gebauer and von Zedtwitz, 2007; Gebauer et al., 2007). EngCo China resolved its ability issue by developing an external ASPN, which primarily consisted of local workshops and dealerships. The ASPN greatly increased EngCo China's ability to be closer to local customers in a vast country and to service the large installed base. Within HQ and EngCo China, there was a realization that they were not, to a large extent, in a position to assume control over the end-user's operations. Moreover, the market was not considered to have matured to the extent that customers were willing to hand over operating responsibility for their processes to EngCo ( $c f$. Gebauer et al., 2008). However, it was considered a potentially viable option in the longer-term, as customer needs changed. In addition, the type of competencies required to offer more advanced services and solutions were still in the early phase of being developed for EngCo China.

- Dynamic 6 - HQ leveraging its ability to draw on global capabilities:

The challenge was then one of developing the necessary abilities locally and transferring knowledge from other markets, in order to provide advanced offerings on a larger scale, once the opportunity emerged. This had implications for monitoring and developing the ability levels of the ASPN. In this respect, HQ had devised a new policy of annually re-accrediting ASPs based on strict ability criteria. However, the targeted training support for ASPs was found wanting and still in its infancy. 
The above dynamics serve to illustrate the complexities of coordinating and aligning the MOA elements across the different actors. We show that a clear motivation and opportunity for enhanced competitiveness via services exists within EngCo and its Chinese subsidiary, though the ability to do so is to a large extent dependent on the ASPN. In this respect, we provide important empirical insights into the role of an external service partner network in attempting to advance services. The extent to which the external service partner is able to deliver advanced services is shown to be an important consideration. Similarly, the extent to which EngCo is dependent on the ASPN raises questions about whether the opportunity can be realized in full. Consequently, achieving alignment between the different actors is potentially critical to successfully growing the service business in China.

\section{DISCUSSION AND CONCLUSION}

In this in-depth exploratory study, we illustrate the complexities and challenges of attempting to advance services and solutions in an emerging market like China. The point of departure for this study was the limited insight in the existing literature into the supply network considerations. This study explored the servitization efforts of EngCo in China by adopting the MOA framework. Using this framework, we contribute to previous studies that have touched upon cultural differences (Gebauer et al., 2007) and the lack of capabilities for delivering services within a country the size of China (cf. Kowalkowski et al., 2011). Similar to these studies, we find that both cultural differences and China's geographical characteristics impact servitization. Specifically, we find that EngCo is conscious of the need for relational bonds with customers, which is achievable through local external partners that possess local customer knowledge. However, offering advanced services and solutions requires investment in developing the abilities of external partners, which involves significant risk on the part of EngCo.

\subsection{Theoretical contribution}

In this study, we make an important theoretical contribution by extending the MOA framework to an inter-organizational level for understanding the complexities and challenges of growing service in an emerging market such as China, rather than focusing within a single organization. Previous studies in the servitization context have tended to examine the elements of MOA independently (Johnstone et al., 2014). In line with other studies, we argue that the MOA elements need not only be mutually reinforcing within an organization (Blumberg and Pringle, 1982; Johnstone et al., 2014) but also across organizations in a network. This presents managerial complexities and challenges of coordinating and aligning the different elements across the different actors. Each of these elements play an important role in enabling or inhibiting strategic change, making it critical for a firm to understand how to instigate motivation, create opportunities and develop abilities. Whether the different elements are supportive or contradictory for the different actors involved at an inter-firm level is an important consideration. Understanding this requires a move away from the purely structural considerations and towards the managerial issues of coordination and alignment of the different MOA elements for the actors involved. For example, motivation of one actor can impact the opportunity and ability of another actor within the supply network. This in turn implies that a key managerial issue is to carefully consider strategies for impacting the elements of other actors in the network in the pursuit of alignment.

While aligning the MOA elements may involve adjustments to structural and infrastructural decision categories (Rudberg and Olhager, 2003), our study suggests this to be much more of a 
dynamic managerial process. In effect, a complex picture of the servitization efforts of EngCo in China emerges, as a dynamic managerial process in which the different actors in the network impact, and are impacted by, the decisions and actions of others. In this study, we contribute to the servitization literature domain by explicitly exploring the challenges of alignment and coordination between multiple sites within a global manufacturer operating in China and its external service partner network. Such inter-firm networks involve a need to pursue harmonization across multiple organizations and multiple sites in order to achieve higher performance, which presents additional managerial challenges (Rudberg and Olhager, 2003). While previous studies on servitization have begun to address the role of external partner networks (Kowalkowski, 2011; Kowalkowski et al., 2016) and buyer-supplier relationships (Bastl et al., 2014; Saccani et al., 2013), the managerial challenges of coordination and alignment are less well explored. In this paper, we make an important contribution by focusing on the issue of external partner networks and the difficulty of aligning and coordinating activities in a supply network using the MOA framework from an interfirm perspective.

Importantly, our findings suggest that servitization requires ongoing managerial efforts of coordination and alignment in order to mutually reinforce the MOA elements. Realizing that changing MOA in one part of the network has implications for the MOA elements in other parts of the network underscores the dynamic nature of such managerial efforts.

\subsection{Managerial contribution}

The findings from this study will be of interest to organizations seeking to expand into emerging markets, such as China, for services. Manufacturers looking to expand their offerings need to consider the capabilities necessary to realize their service strategy. Whether these capabilities are developed internally or dependent on external partners is likely to have ramifications for future service offerings and achieving the strategic vision. The use of an external service network to deliver services may impact the type of services provided. An external service network may not be able to deliver higher value-added services that need to be customized to specific customer needs. There is a requirement to consider the type of service required for different market segments. As such, it may be necessary to concurrently adopt different service strategies that are either standardized or customized to meet specific customer needs (Matthyssens and Vandenbempt, 2010).

Our study suggests that managers need to be cognizant of aligning the three MOA elements, which is particularly challenging given their dynamic relationship and understanding that creating ability in one part of the network may be detrimental to the motivation in other parts of the network. These dynamics are part of the complexities of managing an activity, which is about more than creating the necessary structural alignment. While the extant literature has studied the challenges of servitization, it has primarily focused on addressing these from a configurational perspective. Our findings suggest that the challenges of servitization are dynamic in the sense that they require more than structural changes. The delicate management of relationships, in particular in the context of China, is also an important consideration (Gebauer et al., 2007).

Another important managerial consideration pertains to how an external service network is given recognition and incentivized to perform to set standards. Careful consideration is necessary in respect of both the talent management strategy and how the service partner network is recruited 
and retained. Whether to adopt a host-oriented (polycentric) or home-oriented (ethnocentric) service approach depends on the capabilities, types of services and estimates of market potential. A centralized approach can ensure standardized and uniform service offerings, while a localized approach can be customized to the local needs. This would imply the need for a differentiated approach based on the type of service offerings and market needs. Lastly, knowledge of the market (local needs) and about technological opportunities (potential customer solutions) may imply that for more advanced service offerings and solutions, there is a need for an ethnocentric approach, in close collaboration with a few key customers in the target market, whereas sales of more basic services might be more feasible through a polycentric oriented approach in order to identify the right customers for standardized services via an external service partner network.

\subsection{Limitations and further research}

This study is not without limitations, opening numerous possibilities for further research. Firstly, in line with the research questions, our research builds primarily on qualitative empirical material from the headquarters and Chinese subsidiary of an industrial firm, as well as from members of its service partner network in China. It is important to recognize this context within which the study was conducted. To address this limitation, we have reported extensively on the contextual characteristics of the study to allow other researchers to compare the extent to which their own case studies are similar or different.

Secondly, while the research setting of an industrial firm providing capital equipment to customers within China allows us to explore the challenges of this venture in more detail and thereby contribute to this understudied issue, it also presents opportunities for further research. In particular, it would be interesting to expand the applicability of the MOA framework to other network contexts, such as within the home market of a focal firm, a more balanced service network or by focusing on the MOA elements from the customer perspective in conjunction with the focal firm. Furthermore, researchers may wish to undertake longitudinal case research to explore how the relationships amongst the MOA elements change across the networks over time and carefully investigate their nature in terms of complementarities and potential trade-offs.

Finally, our study is limited in that it provides a causal explanation for the dynamics identified through our analysis, where other relationships between MOA elements could potentially be identified based on further data collection. To address this limitation, as explained, we have provided detailed contextual explanations of the relationships between the MOA elements. However, a promising avenue for further research would be to consider other theoretically possible relationships between MOA elements and identify the appropriateness of these in a larger strategically sampled case population. Notwithstanding the above limitations, this study sheds light on the challenges of servitizing in an emerging market using the MOA framework within a supply network, while expanding the opportunity for further research.

\section{Acknowledgements}

The work presented here was undertaken at Copenhagen Business School as part of the 'Driving Competitiveness through Servitization' project, which is supported by the Danish Industry Foundation (Project number: 2014-0095). We would like to acknowledge the research support provided by Anders Park Egedal, Kai Inga Basner and Lauren Pflueger. Earlier versions of this paper were presented at the EurOMA 2015 conference in Nuechtal, Switzerland and at the 
Academy of Management 2016 conference in Anaheim, CA, USA. We are grateful for the comments of the participants at these conferences. We also acknowledge the constructive comments provided on earlier drafts by Jan Mouritsen, Dane Pflueger, Christian Kowalkowski, Daniel Kindström and Alexey Sklyar; all remaining errors remain our own. Lastly, we acknowledge the many helpful comments from the special issue editors and the two anonymous reviewers.

\section{REFERENCES}

Andrews, J.C. (1988), "Motivation, ability, and opportunity to process information: conceptual and experimental manipulation issues", Advances in consumer research, Vol. 15 No. 1, pp. 219-225.

Argote, L., McEvily, B. and Reagans, R. (2003), "Managing knowledge in organizations: an integrative framework and review of emerging themes", Management science, Vol. 49 No. 4, pp. 571-582.

Baines, T., Lightfoot, H., Peppard, J., Johnson, M., Tiwari, A., Shehab, E. and Swink, M. (2009), "Towards and operations strategy for product-centric servitization", International Journal of Operations \& Production Management, Vol. 29 No. 5, pp. 494-519.

Bastl, M., Johnson, M. and Choi, T. Y. (2013). "Who's seeking whom? Coalition behavior of a weaker player in buyer-supplier relationships", Journal of Supply Chain Management, Vol. 49 No. 1, pp. 8-28.

Bastl, M., Johnson, M., Lightfoot, H., \& Evans, S. (2012). Buyer-supplier relationships in a servitized environment: An examination with Cannon and Perreault's framework. International Journal of Operations \& Production Management, 32(6), 650-675.

Binney, W., Hall, J. and Shaw, M. (2003), "A further development in social marketing application of the MOA framework and behavioral implications", Marketing Theory, Vol. 3 No. 3, pp. 387403.

Blumberg, M. and Pringle, C.D. (1982), "The missing opportunity in organizational research: some implications for a theory of work performance", Academy of management Review, Vol. 7 No. 4, pp. 560-569.

Boudreau, J., Hopp, W., McClain, J.O. and Thomas, L.J. (2003), "On the interface between operations and human resources management", Manufacturing \& Service Operations Management, Vol. 5 No. 3, pp. 179-202.

Bos-Nehles, A.C., Van Riemsdijk, M.J. and Kees Looise, J. (2013), "Employee perceptions of line management performance: applying the AMO theory to explain the effectiveness of line managers' HRM implementation", Human resource management, Vol. 52 No. 6, pp. 861-877.

Boxall, P. and Purcell, J. (2016), Strategy and Human Resources Management, $4^{\text {th }}$ Edition. $^{2}$ Palgrave Macmillan, New York, NY.

Chakkol, M., Johnson, M., Raja, J. and Raffoni, A. (2014), "From goods to solutions: how does the content of an offering affect network configuration?", International Journal of Physical Distribution \& Logistics Management, Vol. 44 Nos 1/2, pp. 132-154.

Chakkol, M., Finne, M., \& Raja, J. (2015). Exploring the Impact of Mergers and Acquisitions on Supply Chain Relationships. In The 22nd International Annual EurOMA Conference 2015.

Choi, T. Y. and Wu, Z. (2009), "Triads in supply networks: theorizing buyer-supplier-supplier relationships", Journal of Supply Chain Management, Vol. 45 No. 1, pp. 8-25.

Corbin, J.M. and Strauss, A.L. (1990), Basics of Qualitative Research: Techniques and Procedures for Developing Grounded Theory, Sage, Newbury Park, CA. 
Delery, J.E. and Shaw, J.D. (2001), "The strategic management of people in work organizations: review, synthesis, and extension", Research in personnel and human resources management, Vol. 20, pp. 165-197.

Demeter, K. and Szász, L. (2013), "Towards solution based thinking: characteristics of servitization at Hungarian manufacturing companies", Journal for East European Management Studies, Vol. 18 No. 3, pp. 309-335.

Dubois, A. and Gadde, L. E. (2002), "Systematic combining: an abductive approach to case research", Journal of business research, Vol. 55 No. 7, pp. 553-560.

Finne, M., \& Holmström, J. (2013). A manufacturer moving upstream: triadic collaboration for service delivery. Supply Chain Management: An International Journal, 18(1), 21-33.

Fischer, T., Gebauer, H. and Fleisch, E. (2008), "Redefining product strategies in China: overcoming barriers to enter the medium market segment", Strategic Direction, Vol. 24 No. 5, pp. 3-5.

Gebauer, H. (2007), "Extending the Service Business in China? Experience of Swiss Companies", Singapore Management Review, Vol. 29 No. 1, pp. 59-71.

Gebauer, H., Wang, C. Beckenbauer, B. and Krempl, R. (2007), "Business-to-business marketing as a key factor for increasing service revenue in China", Journal of Business \& Industrial Marketing, Vol. 22 No. 2, pp. 126-137.

Gebauer, H., Pütz, F., Fischer, T., Wang, C. and Lin, J. (2008), "Exploring maintenance strategies in Chinese product manufacturing companies", Management Research News, Vol. 31 No. 12, pp. 941-950.

Gebauer, H., Kucza, G. and Wang, C. (2011), "Spare parts logistics for the Chinese market", Benchmarking: An International Journal, Vol. 18 No. 6, pp. 748-768.

Gebauer, H. and Fischer, T. (2009), "Exploring service needs in the Chinese manufacturing industry", Chinese Management Studies, Vol. 3 No. 2, pp. 143-154.

Gebauer, H. and von Zedtwitz, M. (2007), "Differences in orientations between Western European and Chinese service organizations", Asia Pacific Journal of Marketing and Logistics, Vol. 19 No. 4, pp. 363-379.

Gebauer, H. (2006), "Entering low-end markets: a new strategy for Swiss companies", Journal of Business Strategy, Vol. 27 No. 5, pp. 23-31.

Hitt, M. A., Beamish, P. W., Jackson, S. E. and Mathieu, J. E. (2007), "Building theoretical and empirical bridges across levels: Multilevel research in management" Academy of Management Journal, Vol. 50 No. 6, pp. 1385-1399.

Järvensivu, T. and Törnroos, J. Å. (2010), "Case study research with moderate constructionism: Conceptualization and practical illustration”, Industrial Marketing Management, Vol. 39 No. 1, pp. 100-108.

Johnstone, S., Wilkinson, A. and Dainty, A. (2014), "Reconceptualizing the Service Paradox in Engineering Companies: is HR a Missing Link?", IEEE Transactions on Engineering Management, Vol. 66 No. 2, pp. 275-284.

Karatzas, A., Johnson, M. and Bastl, M. (2016), "Relationship Determinants of Performance in Service Triads: A Configurational Approach", Journal of Supply Chain Management, (early view).

Katz, H.C., Kochan, T.A. and Weber, M.R. (1985), "Assessing the effects of industrial relations systems and efforts to improve the quality of working life on organizational effectiveness", Academy of Management Journal, Vol. 28 No. 3, pp. 509-526. 
Ketokivi, M. and Choi, T. (2014), "Renaissance of case research as a scientific method", Journal of Operations Management, Vol. 32 No. 5, pp. 232-240.

Kim, H., Hur, D. and Schoenherr, T. (2015), "When buyer-driven knowledge transfer activities really work: a motivation-opportunity-ability (moa) perspective", Journal of Supply Chain Management, Vol. 51 No. 3, pp. 33-60.

King, N. (2004). Using templates in the thematic analysis of texts. In Cassell, C. and Symon, G. (2004), Essential guide to qualitative methods in organizational research, Sage, London.

King, B. G., Felin, T. and Whetten, D. A. (2010), "Perspective-finding the organization in organizational theory: A meta-theory of the organization as a social actor", Organization Science, Vol. 21, No. 1, pp. 290-305.

Kinkel, S. (2012), "Trends in production relocation and backshoring activities: changing patterns in the course of the global economic crisis", International Journal of Operations \& Production Management, Vol. 32 No. 6, pp. 696-720.

Kowalkowski, C. (2011). The service function as a holistic management concept. Journal of Business \& Industrial Marketing, 26(7), 484-492.

Kowalkowski, C., Kindström, D., \& Carlborg, P. (2016). Triadic value propositions: When it takes more than two to tango. Service Science, 8(3), 282-299.

Kowalkowski, C., Kindström, D., \& Witell, L. (2011). Internalisation or externalisation? Examining organisational arrangements for industrial services. Managing Service Quality: An International Journal, 21(4), 373-391.

Kucza, G. and Gebauer, H. (2011), "Global approaches to the service business in manufacturing companies", Journal of Business \& Industrial Marketing, Vol. 26 No. 7, pp. 472-483.

Lambert, D. M. and Cooper, M. C. (2000), "Issues in supply chain management", Industrial marketing management, Vol. 29 No. 1, pp. 65-83.

Li, L.Y. (2011), "Marketing of competence-based solutions to buyers in exploratory relationships: perspective of OEM suppliers", Industrial Marketing Management, Vol. 40 No. 7, pp. 12061213.

Li and Choi (2009).

MacInnis, D.J., Moorman, C. and Jaworski, B.J. (1991), "Enhancing and measuring consumers' motivation, opportunity, and ability to process brand information from ads", The Journal of Marketing, Vol. 55, pp. 32-53.

Maclnnis, D.J. and Jaworski, B.J. (1989), "Information processing from advertisements: toward an integrative framework", The Journal of Marketing, Vol. 53, pp. 1-23.

Matthyssens, P. and Vandenbempt, K. (2010), "Service addition as business market strategy: identification of transition trajectories", Journal of Service Management, Vol. 21 No. 5, pp. 693-714.

McCutcheon, D.M. and Meredith, J.R. (1993), "Conducting case study research in operations management", Journal of Operations Management, Vol. 11 No. 3, pp. 239-256.

Miles, M.B. and Huberman, A.M. (1994), Qualitative data analysis: An expanded sourcebook, 2nd ed., Sage, London.

Morgeson, F. P. and Hofmann, D. A. (1999), "The structure and function of collective constructs: Implications for multilevel research and theory development", Academy of Management Review, Vol. 24 No. 2, pp. 249-265.

Neely, A. (2007), "The Servitization of Manufacturing: an Analysis of Global Trends", paper presented at the 14th EurOMA Conference, Ankara. 
Neely, A. (2008), "Exploring the financial consequences of the servitization of manufacturing", Operations Management Research, Vol. 1 No. 2, pp. 103-118.

Neely, A., Benedettini, O. and Visnjic, I. (2011), "The servitization of manufacturing: further evidence", paper presented at the 18th European Operations Management Association Conference, Cambridge.

Ostrom, A.L., Parasuraman, A., Bowen, D.E., Patrico, L. and Voss, C.A. (2015), "Service research priorities in a rapidly changing context", Journal of Service Research, Vol. 18 No. 2, pp. 127159.

Peirce, C.S. (1903), "Pragmatism as the logic of abduction", The Essential Peirce: Selected Philosophical Writings, Vol. 2, pp. 226-242.

Perlmutter, H.V. (1969), "The tortuous evolution of the multinational enterprise", Columbia Journal of World business, Vol. 4 No. 1, pp. 9-18.

Reiner, G., Demeter, K., Poiger, M. and Jenei, I. (2008), "The internationalization process in companies located at the borders of emerging and developed countries", International Journal of Operations \& Production Management, Vol. 28 No. 10, pp. 918-940.

Reinholt, M.I.A., Pedersen, T. and Foss, N.J. (2011), "Why a central network position isn't enough: the role of motivation and ability for knowledge sharing in employee networks", Academy of Management Journal, Vol. 54 No. 6, pp. 1277-1297.

Rothschild, M.L. (1999), "Carrots, sticks, and promises: a conceptual framework for the management of public health and social issue behaviours", The Journal of Marketing, Vol. 63 No. 4, pp. 24-37.

Rudberg, M., \& Olhager, J. (2003). Manufacturing networks and supply chains: an operations strategy perspective. Omega, 31(1), 29-39.

Saccani, N., Visintin, F., \& Rapaccini, M. (2014). Investigating the linkages between service types and supplier relationships in servitized environments. International Journal of Production Economics, 149, 226-238.

Scott, W. R., \& Davis, G. F. (2015). Organizations and organizing: Rational, natural and open systems perspectives. Routledge.

Spring, M. and Araujo, L. (2013), "Beyond the service factory: Service innovation in manufacturing supply networks", Industrial Marketing Management, Vol. 42 No. 1, pp. 59-70.

Szász, L. and Demeter, K. (2015), "Business models along supply chain position and servitisation: An empirical investigation of European manufacturers", Acta Oeconomica, Vol. 65 No. 3, pp. 367-391.

Siemsen, E., Roth, A.V. and Balasubramanian, S. (2008), "How motivation, opportunity, and ability drive knowledge sharing: the constraining-factor model", Journal of Operations Management, Vol. 26 No. 3, pp. 426-445.

Siggelkow, N. (2007), "Persuasion with case studies", Academy of Management Journal, Vol. 50 No. 1, pp. 20-24.

Vandermerwe, S. and Chadwick, M. (1989), "The internationalization of service", The Services Industries Journal, Vol. 9 No. 1, pp. 79-93.

Vandermerwe, S. and Rada, J. (1988), "Servitization of business: adding value by adding services", European Management Journal, Vol. 6 No. 4, pp. 314-324.

Voss, C., Tsikriktsis, N. and Frohlich, M. (2002), "Case research in operations management", International journal of operations \& production management, Vol. 22 No. 2, pp. 195-219. 
Whetten, D. A., Felin, T. and King, B. G. (2009), "The practice of theory borrowing in organizational studies: Current issues and future directions", Journal of Management. Vol. 35 No. 3, pp. 537-63.

Windahl, C. and Lakemond, N. (2006), "Developing integrated solutions: the importance of relationships within the network", Industrial Marketing Management, Vol. 35 No. 7, pp. 806816.

Wise, R. and P. Baumgartner (1999), "Go downstream: the new profit imperative in manufacturing", Harvard Business Review, Vol. 77 No. 5, pp. 133-141.

Xin, K.K. and Pearce, J.L. (1996), "Guanxi: connections as substitutes for formal institutional support", Academy of management journal, Vol. 39 No. 6, pp. 1641-1658.

Yin, R. K. (2009), Case study research: Design and methods, 4th. Thousand Oaks.

Zhang, M., Zhao, X., Voss, C. and Zhu, G. (2016), "Innovating through services, co-creation and supplier integration: cases from China", International Journal of Production Economics, Vol. 171 No. 2, pp. 289-300. 


\section{Appendix A: Sample of interview protocol}

Company's name:

Interviewee's name:

Interviewee's position:

\section{Company and background (asked to all respondents):}

- Interviewee's background

- Interviewee's roles and responsibilities within the company

- Organizational structure seen from interviewee's perspective

\section{2a. Topics covered with respondents at HQ:}

- The shift towards services - customer-, opportunity-, competition-driven

- Primary motives in the design of new products and services

- Key capabilities for the competitiveness of [company name]

- Global service strategy and implementation in local offices

- Role of distance in implementation the global strategy

- Abilities necessary to become an Authorized Service Partner

- Scope of service offerings

- Opportunities/challenges in adding more services to your products

- Opportunities for [company name] in the Chinese market

\section{2b. Topics covered with respondents in China:}

- The shift towards services

- Key capabilities for the competitiveness of [company name]

- Managing the large market in China

- Opportunities/challenges operating in China

- Strategic motives for China

- Threats impacting strategic plans

- Role of customization and adapting products?

- Assessment of abilities of external service partners with regard to skills level?

- Opportunities/challenges foreseen/experienced in delivering integrated products and services?

\section{2c. Topics covered with ASPN companies:}

- $\quad$ Relationship with [company name]

- Motivation and incentives to sell [company name] products and services?

- To what extent is what [company name] does unique in your opinion?

- Impact of services on client relationships

- Abilities sought for in hiring within the service organization

- Assessment by [company name] of external service partners abilities

- Opportunities/challenges foreseen/experienced in delivering services

- Goals set by [company name] for your service organization?

\section{General closing questions (asked to all respondents):}

- Written background information that we can take away?

- Is there anything we have overlooked? 